\title{
LEXICON BORROWINGS FROM ARABIC IN SUNDANESE SPEECH LEVEL SYSTEM \\ Wahya $^{1^{*}}$, Hazbini' ${ }^{2}$ \\ ${ }^{1 * 2}$ Faculty of Cultural Sciences, Budaya Universitas Padjadjaran, Bandung, Indonesia. \\ Email: ${ }^{*}$ wahya@unpad.ac.id, ${ }^{2}$ hazbini@unpad.ac
}

Article History: Received on $28^{\text {th }}$ March 2020, Revised on $18^{\text {th }}$ May 2020, Published on $17^{\text {th }}$ June 2020

\begin{abstract}
Purpose of the study: This article examines a lexicon of Arabic borrowings used in the Sundanese speech level system. A lexicon of borrowed words refers to a lexicon of Arabic loanwords that are used across different speech level codes. A lexicon of borrowings consists of words from a donor language that have been adopted into a recipient language for certain purposes.

Methodology: In this descriptive and qualitative research, the data were collected utilizing the observation method and recording technique. The data for this descriptive-qualitative research were collected using observing the use of words prescribed in a Sundanese dictionary namely Kamus Undak Usuk Basa Sunda (Dictionary of Sundanese Speech Level) by Tamsyah, published in 2015 and Kamus Etimologi Basa Sunda (Dictionary of Sundanese Etymology) also by Tamsyah, published in 2017. The data were analyzed by using an identical method and a lexico-semantic approach. The sources of the data were chosen as data source samples by taking into account the availability of the data required in them.
\end{abstract}

Main Findings: The findings of the research study reveals that a lexicon of nineteen words borrowed from Arabic commonly used in coarse, middle, and refined codes, with coarse usage predominating. While some of these words retain a similar form to that of the original Arabic, others have transformed. The nineteen words are as follows: asal, makam, berekah, Abdi, alim, udur, hed, Kabar, hawatir, maksud, maot, mayit, lahir, saum, sabab, salat, sunatan, surat, and umur.

Applications of the study: Introduction of Arabic lexicon to the Sundanese speech system occurred through a process of the loan. While some of these words retain a similar form to that of the original Arabic, others have transformed. It is a transformation that causes the words to be used in different codes in the Sundanese speech level system.

Novelty/Originality of the study: In Sundanese, speech level is considered a sociolinguistic innovation. Both the written and spoken forms of the language, together with all their variations and functions, are vital amidst the daily dynamics of the Sundanese people's life. Hence, this article discusses the use of the lexicon of Arabic borrowings across different codes of the Sundanese speech level system. The current study is novel as it's the first study that compares the Arabic and Sundanese language and found out the words that are originated from Arabic.

Keywords: Borrowing, Speech Level, Sociolinguistics, Sundanese, Ethnic Group, Language.

\section{INTRODUCTION}

The Sundanese language, which is very closely tied to the Sundanese culture, is an important medium of verbal communication among Sundanese ethnic groups. Both the written and spoken forms of the language, together with all their variations and functions, are vital amidst the daily dynamics of the Sundanese people's life. Spoken by Sundanese ethnic groups living in West Java, Banten, and other provinces in Indonesia, the Sundanese language belongs to the Austronesian family.

Sundanese, like Javanese, Balinese, and Madurese, is a language in which the speech level system is recognized. Speech level, or undakusuk in Sundanese, is a sociolinguistic system or rule that resulted from an externally influenced innovation. The undakusuk system came to be gradually used as a result of continuous contact with the Javanese language, with its concept of unggah-ungguh. The system was brought from Mataram and was introduced into Sundanese by Sundanese aristocrats. According to Rosidi (1987), such a feudal system of stratifying language use began during the reign of Mataram King Sultan Agung(26) in the $17^{\text {th }}$ century (Tamsah Kamus Undak Usuk). Later, however, the undakusuk system was considered as a code of politeness in speech (Sudaryat, Prawirasumantri, \& Yudibrata, 2013). Sudanese cultural thinkers/scholars, therefore, have different views on the undakusuk system. While some advocate rigorous use of the system, others tend to be more lenient. This issue once became a polemic among them (Mochtar, 2018; Ruskhan, 2007; Rosidi, 1987, 2011; Rana, Qin, Bates, Luster, \& Saltarelli, 2011; Sudaryat et al., 2013).

Geographically, however, not all dialects impose the use of undakusuk in speech. Speech level is not known among Sundanese speakers in Banten, Indramayu, and northern Bogor, for example. Hadi (1991)categorizes the Sundanese undakusuk into only three levels, namely basaloma 'coarse code', basalemes (keursorangan), 'refined code (for speaking about oneself), and basalemes (keurkabatur) 'refined code (for speaking with other people)'. Meanwhile, Tamsyah (2015), 
Kamus Undak Usuk refers to the three speech levels as basakasar 'coarse code', basasedeng 'middle code', and basalemes 'refined code'. In this article, the term 'code' is used to refer to the term basa, which denotes speech level. As a result of such stratification, some words may have variants that are used as equivalents or synonyms in different speech levels.

The Sundanese language is one of the languages in which speech level or undakusuk is recognized. Speech level is a system or rule that regulates conversation based on social factors such as age and social status. In its practical use speech level is categorized into coarse, middle, and refined codes. The use of these codes depends on how a speaker sees his/her position with an addressee. In addition to the three codes above, these two additional codes, namely very coarse and very refined codes, are also quite common. In each code, some words have their semantically synonymous counterparts in the other codes (Anderson, 1997).

The lexicon used in the different speech level codes consists of words of Sundanese origin and borrowings from nonSundanese languages. In Sundanese, speech level first came to be used as an innovation influenced by the Javanese language. It is therefore not a surprising fact that many words currently used across different speech level codes in Sundanese derive from Javanese. There are also words borrowed from other languages, for example, old Javanese and Arabic languages. Past contact and interaction between speakers of Sundanese and Arabic were responsible for such borrowings. Contact between the two languages began during or following the introduction of Islam to the Sundanese land (Sharkey, 2008; Wahya, Lyra, Permadi\&Kosim, 2018). Absorption and popularization of words borrowed from Arabic occurred concurrently with the wide-scale conversion to Islam and the practice of Islamic teachings among Sundanese people (Hassan, 1963; Naniya, 2000; Wahya et al. 2018). Words of Arabic origin are widely used across different speech level codes but this topic has not received much scholarly attention. Unlike Sundanese, the Arabic language recognizes no stratification of language use. In Sundase, however, borrowed words of Arabic origin are used in different codes. It can be concluded from this fact that the Arabic language had influenced Sundanese even before the introduction of the undak usuk system into Sundanese.

This article discusses the use of the lexicon of Arabic borrowings across different codes of the Sundanese speech level system: what words are used in the different codes and what transformation these words have undergone. The aim is to describe the lexicon of Arabi borrowings used in the different levels of undak usuk, to describe in which code the words are used, and to describe the transformation the words have undergone.

Social factors play an important role in the use of Sundanese among different speech participants (Musgrave, \& Bradshaw, 2014). According to Kats and Soeriadiradja (1982), the social factor may include status, position, and age. Other scholars mention that social factor includes the followings: rank, status, and age (Coolsma, 1985; Hatoss, \& Sheely, 2009; Sudaryat, 2015); power, position, and degree of closeness or intimacy between a speaker and the person being talked about (Sudaryat et al., 2013; Perry, 2007); age, position, speech situation, addressee, conversation topic Tamsyah (2015), Kamus Undak Usuk. Consideration of different factors in speech is known as speech level system or undak usuk in Sundanese. Tamsyah (2015), Kamus Undak Usuk defines speech level as a linguistic variation of which use is determined by age, position, speech situation between speaker and addressee, and the topic of conversation. According to Rahardi (2010) as a system of codes in a speech community, speech level is determined by the relation between speaker and addressee. According to Sudaryat et al. (2013), as linguistic variation, speech level is based on the speaker's attitude and is the reflection of the speaker's politeness in speech. Sudaryat et al. (2013) argue that in Sundanese there are two speech level codes namely refined or respectful and coarse or intimate. In terms of refined speech level, respect is further categorized into respect for oneself and respect for others (Anderson, 1993; Indrayani, 2011; Sudaryat et al., 2013).

The degree of respect and intimacy affects the social distance between a speaker and an addressee. The use of respectful speech level implies the presence of social distance between the speaker and his or her addressee. Conversely, the use of intimate speech level eliminates such social distance. A Sundanese speaker must consider social distance in conversation. Social distance can be defined as one's perception of whether he or she has the same social position as other people (Shamir, 1995; Richard, Platt, \& Weber, 1987). This article focuses on the use of words borrowed from Arabic in the Sundanese speech level system.

The distanceless social relation is reflected in casual and intimate forms of speech. Casual speech form is used in spoken communication among friends during such casual occasions as recreation or friendly sporting events, while an intimate speech is used among family members or very close friends. Both forms are marked by incomplete structure, clear articulation, and short responses (Horton \& Richard Wohl, 1956; Nababan, 1986; Schumann, 1976; Xiaoyun\&Siqi, 2018; Yang, \& Chang, 2017).

This article examines a lexicon of Arabic borrowings used in the Sundanese speech level system. A lexicon of borrowed words refers to a lexicon of Arabic loanwords that are used across different speech level codes. A lexicon of borrowings consists of words from a donor language that have been adopted into a recipient language for certain purposes. In this context, the word 'adopt' is synonymous with 'loan' or 'borrow'. In this article, however, it refers to 'borrow' or 
'borrowing'. According to Rushkan (2007), borrowing is the process of adopting patterns or elements from a donor language to be used in a recipient language. Rushkan (2007) asserts that all types of borrowing involve two processes, namely importation and substitution. Furthermore, he adds, borrowing can include the adoption of (1) loanwords, (2) loan blends, and (3) loan shifts (Rushkan 27).

\section{DATA AND METHOD}

Based on the data source used, the following nineteen words borrowed from Arabic were found to be in use in different Sundanese undakusuk or speech levels: asal 'origin', makam 'grave', berekah 'blessing', abdi 'I', the aim would not/refuse', udur 'ill/sick', hed, 'menstruation, kabar 'news/tidings', hawatir 'concerned/worried', maksud 'meaning', maot 'die/pass away', mayit 'dead body/corpse', Lahore born', saum 'fasting', sababe 'cause/reason/because', salat 'salat/prayer', sunatan 'circumcision', surat 'letter', and umur 'age'. It is important to note that in addition to the word surat 'letter', which is similar in form to the original, there is also the word sera $t$ 'write', which derived from the same Arabic word but is different in form due to the replacement of the vowel /u/ with the vowel /o/, hence serat, and the word certain, to which the suffix -an is added, making seratan thus a polymorphemic word. Due to these processes, the words surat and seratan are thus two separate dictionary entries in addition to surat.

In Sundanese, speech level is considered a sociolinguistic innovation. Therefore, it is not surprising that words borrowed from other languages are used across different speech levels. As mentioned earlier, the speech level in Sundanese consists of three different. Synonymous words are used to meet the rules of use in the three codes. Some of these words are borrowed from Arabic and have undergone certain adaptations. The nineteen Arabic borrowings used across Sundanese speech levels are presented in Table 1 below.

Table 1: Lexicon of Words Borrowed from Arabic in Sundanese Speech Level System

\begin{tabular}{|c|c|c|c|}
\hline No. & $\begin{array}{l}\text { Lexicon of Arabic Borrowings } \\
\text { (Tamsyah, 2015) }\end{array}$ & $\begin{array}{l}\text { Arabic Etymology } \\
\text { (Tamsyah, 2017) }\end{array}$ & Meaning \\
\hline 1 & asal (T, 2015: 22) & ușulun(2017: 34) & Origin \\
\hline 2 & makam (T, 2015: 23) & maqa:mun(2017: 142) & $\begin{array}{l}\text { a grave, place where a dead person is } \\
\text { buried }\end{array}$ \\
\hline 3 & berekah $(\mathrm{T}, 2015: 32)$ & baraka:tun((2017: 47) & healthy \\
\hline 4 & abdi $(\mathrm{T}, 2015: 47)$ & 'abdun(2017: 18) & I \\
\hline 5 & $\operatorname{alim}(\mathrm{T}, 2015: 50)$ & 'aliimun(2017: 6) & would not, refuse \\
\hline 6 & udur (T, 2015: 54) & użurun(2017: 204) & ill, sick \\
\hline 7 & hed (T, 2015: 60) & haidun(2017: 93) & Menstruation \\
\hline 8 & kabar (T, 2015: 69) & khabarun(2017: 113) & news, tidings \\
\hline 9 & hawatir(T, 2015: 72) & khawa:ti:run(2017: 93) & concerned, worried \\
\hline 10 & maksud (T, 2015: 84) & maqșu:dun(2017: 142) & Meaning \\
\hline 11 & $\operatorname{maot}(\mathrm{T}, 2015: 86)$ & $\operatorname{mawt}(2017: 44)$ & die, pass away \\
\hline 12 & mayit $(\mathrm{T}, 2015: 86)$ & mayyitun(2017: 146) & dead body, corpse \\
\hline 13 & lahir (T, 2015: 95) & żahirun(2017: 134) & outside, external \\
\hline 14 & $\operatorname{saum}(\mathrm{T}, 2015: 105)$ & șaumun(2017: 185) & fast(ing) \\
\hline 15 & $\operatorname{sabab}(\mathrm{T}, 2015: 110)$ & $\operatorname{sababun}(2017: 180)$ & (be)cause, reason \\
\hline 16 & salat, solat $(\mathrm{T}, 2015: 112)$ & șala:tun(2017: 181) & salat, prayer \\
\hline 17 & sunatan $(\mathrm{T}, 2015: 119)$ & sunnatun(2017: 204) & circumcision \\
\hline \multirow[t]{3}{*}{18} & $\operatorname{surat}(\mathrm{T}, 2015: 119)$ & su:ratun(2017: 194) & Letter \\
\hline & $\operatorname{serat}(\mathrm{T}, 2015: 127)$ & su:ratun(2017: 194) & Write \\
\hline & seratan $(T, 2015: 128)$ & su:ratun(2017: 194) & $\begin{array}{l}\text { Writing, inscription, (hand)written } \\
\text { text }\end{array}$ \\
\hline 19 & umur $(\mathrm{T}, 2015: 131)$ & 'umrun((2017: 204) & Age \\
\hline
\end{tabular}

Note: $\mathrm{T}=$ Tamsyah

The data for this descriptive-qualitative research were collected using observing the use of words prescribed in a Sundanese dictionary namely Kamus Undak Usuk Basa Sunda (Dictionary of Sundanese Speech Level) by Tamsyah, published in 2015 and Kamus Etimologi Basa Sunda (Dictionary of Sundanese Etymology) also by Tamsyah, published in 2017. The data were analyzed by using an identical method and a lexico-semantic approach. The sources of the data were chosen as data source samples by taking into account the availability of the data required in them. 
The research followed the following procedures: (a) library research: to study the results of previous studies and theories related to the linguistic phenomenon of borrowing and determine an appropriate approach to analyze the data namely a theory proposed by Ruskhan (2007); (b) data collection: to identify in the aforementioned dictionaries entries borrowed from Arabic; (c) data selection: to select entries that would be relevant for the study; (d) data sorting: to sort data containing words borrowed from Arabic; (e) data analysis based on the research questions; (f) conclusion drawing: to synthesize data analysis results; (g) result presentation: to write a paper or article based on the study.

\section{FINDINGS AND DISCUSSION}

\section{The Use of Arabic Borrowings in Sundanese Speech Level Codes}

There are words borrowed from Arabic that are recognized in the Sundanese speech level system and are used in the coarse, middle, and refined codes. How the nineteen Arabic borrowings are used in the Sundanese speech level system is described below. There are two important things to note related to in which code the borrowed words are used and what change of form they have undergone (Sharkey, 2008).

\section{Arabic borrowings used in coarse code}

In coarse code, the following thirteen words borrowed from Arabic are used: asal, berekah, hed, Kabar, hawatir, maksud, maot, mayit, sabab, salat, sunatan, surat, and umur. The three words have their equivalents in the other two codes, the middle and refined codes. The word asal, for example, has its equivalents, namely kawit and kawit in the middle and refined codes respectively. The following table presents the thirteen borrowed words used in the coarse code and their equivalents in the other two codes (Wahya et al. 2018).

Table 2: Thirteen Borrowed Words of Arabic Origin Used in Coarse Code

\begin{tabular}{llll}
\hline No. & Speech Level Code & \\
\hline & Coarse & Middle & Refined \\
\hline 1 & asal & Kawit & Kawit \\
\hline 2 & berekah & pangesto, ayahibar, wilujeng & pangesto, ayahibar, wilujeng \\
\hline 3 & hed & udursasih & Kareseban \\
\hline 4 & Kabar & Wartos & Wartos \\
\hline 5 & hawatir, watir & Hawatos & Hawatos \\
\hline 6 & maksud & Maksad & Maksad \\
\hline 7 & maot & nilar, tilardunya, ngantunkeun & Pupus \\
\hline 8 & mayit & Layon & Layon \\
\hline 9 & sabab & Margi & Margi \\
\hline 10 & sunatan & Beresihan & Sepitan \\
\hline 11 & salat & Netepan & Netepan \\
\hline 12 & surat & Serat & Serat \\
\hline 13 & umur & Yuswa & Yuswa \\
\hline
\end{tabular}

Sociolinguistically, words used in the coarse code indicate an intimate, distanceless relation between speakers. The words of Arabic origin in this code are used for that purpose. Borrowed words of Arabic origin are used because the concept represented by those words did not exist in the Sundanese language. Thus, when the Sundanese language borrowed a word from Arabic, it also borrowed the concept semantically represented by that very word (Nababan, 1986).

\section{Arabic borrowings used in middle code}

The lexicon of Arabic borrowings used in the middle code of the Sundanese speech level consists of the following words: makam, abdi, alim, udur, serat, and seratan. These six words have their equivalents in coarse and refined codes. For example, the word makamis equivalent with the words astana and pajaratan or pasarean in coarse and refined codes respectively. The word makes itself is also used in refined code (Coolsma, 1985; Hatoss, \&Sheely, 2009; Sudaryat, 2015).

Table 3: Five Words of Arabic Origin used in Middle Code

\begin{tabular}{llll}
\hline No. & Speech Level Code & & \\
\hline & Coarse & Middle & Refined \\
\hline 1 & Astana & Makam & makam \\
\hline 2 & kuring & Abdi & abdi \\
\hline 3 & embung & Alim & teukersa \\
\hline 4 & gering & Udur & teudamang \\
\hline
\end{tabular}




\begin{tabular}{llll}
\hline 5 & Kawin & Nikah & nikah \\
\hline 6 & surat & Serat & serat \\
\hline & Tulis & Serat & serat \\
\hline & tulisan & Seratan & seratan \\
\hline
\end{tabular}

Words used in the middle code indicate the presence of distance between speakers. The Arabic borrowings in the table above are used in middle code communication for that purpose. Words of Arabic origin are used in the middle code because they have a more polite or meaning or ameliorative sense compared to the meaning of their counterpart in the coarse code (Ruskhan, 2007).

\section{Arabic borrowings used in refined code}

The following three words are of Arabic origin and are used in Sundanese refined code communication: makam, saum, and seratan. These words have their equivalents in both coarse and middle codes. For example, the word saum is equivalent to puasa and puasa in coarse and refined codes respectively (Indrayani, 2011).

Table 4: Three Words of Arabic Origin Used in Refined Code

\begin{tabular}{llll}
\hline No. & Speech Level Code & & Middle \\
\hline & Coarse & Makam & Makam \\
\hline 1 & Astana & Puasa & Saum \\
\hline 2 & Puasa & Serat & Serat \\
\hline 3 & Surat & Serat & Serat \\
\hline 4 & Tulis & Tulisan & Seratan \\
\hline 5 & Tulisan &
\end{tabular}

Words used in refined code indicate a far distance between speakers. The Arabic borrowings are used in refined code for this purpose. These Arabic borrowings are used across the coarse, middle, and refined codes in the Sundanese undakusuk system. Besides, according to Tamsyah (2015), Kamus Undak Usuk, there are also borrowed words of Arabic origin that are used in base lemespisan 'very refined code', e.g. the word lahir (derived from ẓahirun), which has been transformed into the word ngalahir 'to say' (95).

Table 5 below lists nineteen words borrowed from Arabic. The following abbreviations are used to indicate speech level codes: $\mathrm{CC}=$ Coarse Code MC = Middle Code $\mathrm{RC}=$ Refined Code; and VRC $=$ Very Refined Code.

Table 5: Lexicon of Arabic Borrowings in Sundanese Speech Level

\begin{tabular}{|c|c|c|c|c|}
\hline No. & $\begin{array}{c}\text { Lexicon of Arabic } \\
\text { Borrowings (Tamsyah, } \\
2015)\end{array}$ & $\begin{array}{l}\text { Arabic Etymology } \\
\text { (Tamsyah, 2017) }\end{array}$ & Meaning & $\begin{array}{l}\text { Speech Level } \\
\text { Code }\end{array}$ \\
\hline 1 & $\operatorname{asal}(\mathrm{T}, 2015: 22)$ & ușulun(2017: 34) & Origin & $\mathrm{CC}$ \\
\hline 2 & makam $(\mathrm{T}, 2015: 23)$ & maqa:mun(2017: 142) & $\begin{array}{l}\text { a grave, place where a dead } \\
\text { person is buried }\end{array}$ & $\mathrm{MC}, \mathrm{RC}$ \\
\hline 3 & berekah $(\mathrm{T}, 2015: 32)$ & baraka:tun((2017: 47) & healthy & $\mathrm{CC}$ \\
\hline 4 & abdi $(\mathrm{T}, 2015: 47)$ & 'abdun(2017: 18) & $\mathrm{I}$ & $\mathrm{MC}$ \\
\hline 5 & $\operatorname{alim}(\mathrm{T}, 2015: 50)$ & 'aliimun(2017: 6) & would not, refuse & $\mathrm{MC}$ \\
\hline 6 & udur (T, 2015: 54) & użurun(2017: 204) & ill, sick & $\mathrm{MC}$ \\
\hline 7 & hed (T, 2015: 60) & haidun(2017: 93) & Menstruation & $\mathrm{CC}$ \\
\hline 8 & $\operatorname{kabar}(\mathrm{T}, 2015: 69)$ & khabarun(2017: 113) & news, tidings & $\mathrm{CC}$ \\
\hline \multirow[t]{2}{*}{9} & hawatir(T, 2015: 72) & khawa:ti:run(2017: 93) & concerned, worried & $\mathrm{CC}$ \\
\hline & hawatos(T, 2015: 72) & & & \\
\hline 10 & maksud (T, 2015: 84) & maqșu:dun(2017: 142) & Meaning & $\mathrm{CC}$ \\
\hline 11 & $\operatorname{maot}(\mathrm{T}, 2015: 86)$ & $\operatorname{mawt}(2017: 44)$ & die, pass away & $\mathrm{CC}$ \\
\hline 12 & mayit $(\mathrm{T}, 2015: 86)$ & mayyitun(2017: 146) & dead body, corpse & $\mathrm{CC}$ \\
\hline 13 & lahir $(\mathrm{T}, 2015: 95)$ & zahirun(2017: 134) & outside, external & VRC \\
\hline 14 & $\operatorname{saum}(\mathrm{T}, 2015: 105)$ & șaumun(2017: 185) & fast(ing) & $\mathrm{RC}$ \\
\hline 15 & $\operatorname{sabab}(\mathrm{T}, 2015: 110)$ & $\operatorname{sababun}(2017: 180)$ & (be)cause, reason & $\mathrm{CC}$ \\
\hline 16 & salat, solat $(\mathrm{T}, 2015: 112)$ & șala:tun(2017: 181) & salat, prayer & $\mathrm{CC}$ \\
\hline 17 & sunatan $(\mathrm{T}, 2015: 119)$ & sunnatun(2017: 204) & Circumcision & $\mathrm{CC}$ \\
\hline 18 & $\operatorname{surat}(\mathrm{T}, 2015: 119)$ & su:ratun(2017: 194) & Letter & $\mathrm{CC}$ \\
\hline
\end{tabular}




\begin{tabular}{lllll}
\hline & serat $(\mathrm{T}$, 2015: 127) & su:ratun(2017: 194) & Write & MC, RC \\
\hline seratan $(\mathrm{T}, 2015: 128)$ & su:ratun(2017: 194) & $\begin{array}{l}\text { writing, } \\
\text { (hand)written text }\end{array}$ & inscription, & MC, RC \\
\hline 19 & umur (T, 2015: 131) & 'umrun((2017: 204) & Age & CC \\
\hline
\end{tabular}

Transformation of Arabic Borrowings in Sundanese Speech Level

The adoption of the nineteen Arabic words into Sundanese vocabulary occurred through a process of borrowing or importation, which means that the words still retain their original form fully or partially after undergoing a certain change of

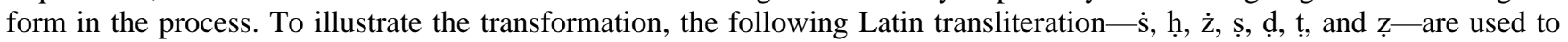

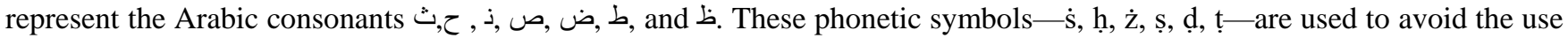
of double symbols to represent one phonetic sound, hence one single symbol for one phonetic sound.

The process of borrowing of the nineteen Arabic words into Sundanese, particularly into its speech level system, can be described briefly as follows. The word asal derives from the Arabic dari ushulun. The syllable /un/ is omitted; the vowel /u/ in the second and third syllables is replaced by $/ a /$; and the consonant $/ s+$ becomes $/ s /$. The word makam comes from maqaamun. The final sound $/ u n /$ is omitted; the consonant $/ q /$ is replaced by $/ k /$. The word berekah is originally barakaatun in Arabic. Again, the final /un/ is omitted; the vowel /a/ in the first and second syllables becomes $/ a /$; and the consonant $/ t /$ becomes $/ \mathrm{h} /$. The word alim derives from 'aliimun. The sound /un/ is omitted and the consonant $/ \dot{\mathbf{z}} /$ is replaced by /d/. The word hed derives from haidlun. The final sound /un/ is omitted; the diphtong /ai/has undergone monophthongisation and become /e/; and the consonant / $/ /$ is replaced by /d/. The word kabar comes from khabarun. The final /un/ is omitted; the consonant $/ \mathrm{k} h /$ is replaced by $/ \mathrm{k} /$. The word hawatir is originally khawaatiirun. The final $/ u n /$ is omitted; the consonant $/ \mathrm{kh} /$ is replaced by $/ h /$. The word maksud derives from maqsuudun. The final sound /un/ is omitted; the consonant $/ q /$ is replaced by $/ k /$; and the consonant $/ \mathrm{s} /$ becomes $/ \mathrm{s} /$. There is also the word maksad, which derives from maksud. The vowel $/ u /$ becomes $/ a /$. The word maot comes from the Arabic mawt. The vowel $/ u /$ becomes $/ o /$. The word may is originally mayyitun. The final /un/ is omitted; the geminate /yy/ becomes / $/$ /. The word lahir derives from dzhahirun. The sound /un/ is omitted and the consonant /z / becomes /l/. The word saum comes from shaumun. The final /un/ is omitted and the consonant /ș/ is replaced by $/ \mathrm{s} /$. The word sabab derives from sababun. The sound /un/ is omitted. The word salat is from shalatun. The sound /un/ is omitted and the consonant /ș/ becomes /s/. In Sundanese, the word solat is also used alternatively. In the case of the latter, the vowel $/ o /$ is used instead of $/ a /$. The word sunatan derives from sunnatun. The vowel $/ u /$ in the last syllable is replaced by $\mid a /$. The word surat comes from suuratun. The sound /un/ is omitted. There is also the word serat, which uses the vowel / $/$ / in the first syllable, instead of $/ u /$. The wordumur derives from 'umrun'. The final sound $/ n /$ is omitted. The word has also undergone a process of metathesis, by which the position of the vowel $/ u /$ in the second syllable is moved to precede the consonant $/ r /$.

\section{CONCLUSION}

Based on the data sources used in the study, nineteen words are borrowed from Arabic and are used in the Sundanese speech level system. Of the nineteen words, one borrowed word, namely surat that has three different meanings. The word surah means letter or mail; its variation, serat, means write; and seratan, to which suffix '-an' is added, means writing, inscription, or written text. Thirteen of the nineteen words are used in coarse code, 5 in middle code, 3 in refined code, and 1 in very refined code. The introduction of the Arabic lexicon to the Sundanese speech system occurred through a process of the loan. While some of these words retain a similar form to that of the original Arabic, others have transformed. It is a transformation that causes the words to be used in different codes in the Sundanese speech level system.

\section{LIMITATION AND STUDY FORWARD}

This research only observes the lexicon of Arabic borrowings used in the Sundanese speech level system. In future other languages can be considered and compared with Sundanese. Moreover, future research can reconsider the 19 Arabic borrowings taken in this research to increase the generalizability of current investigation findings.

\section{ACKNOWLEDGMENT}

This research is an independent study that is not funded by any institution and is a form of sharing between authors. Thanks goes to all people who have participated in making this study possible.

\section{AUTHORS CONTRIBUTION}

Wahya contributed to the concepts, theories, and methodology. These concepts were discussed with Hazbini. The Data are gathered by Hazbini. Furthermore, the data are processed and analyzed by Hazbini. The results of the study were reviewed by, both scholars. 


\section{REFERENCES}

1. Anderson, E. A. (1993). Speech levels: the case of Sundanese. Pragmatics, 3(2), 107-136. https://doi.org/10.1075/prag.3.2.01and

2. Anderson, E. A. (1997). The Use of Speech Levels in Sundanese. Papers in Southeast Asian Linguistics, (16), 1-45.

3. Coolsma, S. (1985). Sundanese speech art(H.Widjajakusumah \& Y. Rusyana, Trans.). Jakarta, Indonesia: Djambatan.

4. Hadi, A. (1991). Peperenian: Kandaga, miscellaneous, secret language. Bandung, Indonesia: Geger Sunten, 1991.

5. Hassan, Y. F. (1963). The penetration of Islam in eastern Sudan. Sudan Notes and Records, 44, 1-8.

6. Hatoss, A., \& Sheely, T. (2009). Language maintenance and identity among Sudanese-Australian refugeebackground youth. Journal of Multilingual and Multicultural Development,30(2), 127-144. https://doi.org/10.1080/01434630802510113

7. Hatoss, A., \& Sheely, T. (2009). Language maintenance and identity among Sudanese-Australian refugeebackground youth. Journal of Multilingual and Multicultural Development,30(2), 127-144. https://doi.org/10.1080/01434630802510113

8. Horton, D., \& Richard Wohl, R. (1956). Mass communication and para-social interaction: Observations on intimacy at a distance. Psychiatry, 19(3), 215-229. https://doi.org/10.1080/00332747.1956.11023049

9. Indrayani, L. M. (2011). Language vitality: A case on Sundanese language as a surviving indigenous language. In International Seminar Language Maintenance and Shift, Pandanaran Semarang, Indonesia.

10. Kats, J. K. \&Soeriadiradja, M. (1982).Sundanese grammar and phrases.Jakarta, Indonesia: Djambatan.

11. Mochtar, M. (2018). Language education policy at schools in the era of Southeast Asian economic community integration. Journal of Advanced Research in Social Sciences and Humanities, 3(3), 95-101. https://doi.org/10.26500/JARSSH-03-2018-0302

12. Musgrave, S., \& Bradshaw, J. (2014). Language and social inclusion: Unexplored aspects of intercultural communication. Australian Review of Applied Linguistics, 37(3), 198-212. https://doi.org/10.1075/aral.37.3.01mus

13. Nababan, P.W.J. (1986).Sociolinguistics: An introduction. Jakarta, Indonesia: Gramedia.

14. Naniya, T. M. (2000). Arab settlers in sub-Saharan Africa: A survey of their Influence on some central Sudanese states. Kano Studies, 1(1), 1-12.

15. Permadi, (2019). The Sundanese language fatis in a Sundanese-language fabricated story as an emotion revealer. Bandung, Indonesia: Unpad Press.

16. Perry, K. (2007). Sharing stories, linking lives: Literacy practices among Sudanese refugees. Cultural practices of literacy: Case studies of language, literacy, social practice, and power, 57-84.

17. Rahardi, R. K. (2010).About the study Lexis code and error code. Bogor, Indonesia: Ghalia Indonesia. 2010.

18. Rana, M., Qin, D. B., Bates, L., Luster, T. O. M., \& Saltarelli, A. (2011). Factors related to educational resilience among Sudanese unaccompanied minors. Teachers College Record, 113(9), 2080-2114.

19. Richards, R., Platt, J., \&Weber, H. (1987). Longman dictionary of applied linguistics. Harlow: Longman.

20. Rosidi, A.(1987). Polemic youngest pallet language. Bandung, Indonesia: Mangle Panglipur.

21. Rosidi, A. (2011).Sunda rhino \& Sunda tiger language learning failure. Jakarta, Indonesia: Pustaka Jaya.

22. Ruskhan, A. G. (2007).Arabic language in Indonesian studies on voting. Jakarta, Indonesia: Grasindo.

23. Schumann, J. H. (1976). Social distance as a factor in second language acquisition. Language Learning, 26(1), 135143. https://doi.org/10.1111/j.1467-1770.1976.tb00265.x

24. Shamir, B. (1995). Social distance and charisma: Theoretical notes and an exploratory study. The Leadership Quarterly, 6(1), 19-47. https://doi.org/10.1016/1048-9843(95)90003-9

25. Sharkey, H. J. (2008). Arab identity and ideology in Sudan: The politics of language, ethnicity, and race. African Affairs, 107(426), 21-43. https://doi.org/10.1093/afraf/adm068

26. Sudaryat, Y. (2015). The Mindset of Sundanese People in Their Language Expressions. Indonesian Journal of Applied Linguistics, 5(1), 126-133. https://doi.org/10.17509/ijal.v5i1.839

27. Sudaryat, Y., Prawirasumantri, A.,\& Yudibrata, K. (2013).The language today, Bandung, Indonesia: Yrama Widya.

28. Tamsyah, B. R. (2015).Dictionary youngest Pallet language.Bandung, Indonesia: Geger Sunten.

29. Xiaoyun, P. \& Siqi, M. (2018). The number of the virtual learning environment and their effective using impact on students' information literacy. Journal of Advances in Humanities and Social Sciences 4(2), 93-103. https://doi.org/10.20474/jahss-4.2.4

30. Yang, S. C., \& Chang, C. M. (2017). Transnational marriage in Taiwan: Challenges faced and adaptation strategies adopted in experiencing a different culture. International Journal of Humanities, Arts and Social Sciences, 3(4), 142-147. https://doi.org/10.20469/ijhss.3.20001-4 